\title{
Technology Planning System as a Decision Support Tool for Dairy Farms in Hungary
}

\section{Tímea Gál*, Lajos Nagy**, Lóránt Dávid***, László Vasa****, Péter Balogh**}

*University of Debrecen CAAES Faculty of Applied Economics and Rural Development, Institute of Marketing and Commerce, Böszörményi út 138, 4032

Debrecen, Hungary, e-mail:galtimea@agr.unideb.hu

**University of Debrecen CAAES Faculty of Applied Economics and Rural Development, Institute of Economic Analitical Methodology and Applied Informatics, Department of Economic Analysis and Statistics, Böszörményi út 138, 4032 Debrecen, Hungary, e-mail: nagyl@agr.unideb.hu, baloghp@agr.unideb.hu

***Károly Róbert College, Institute of Tourism, Regional Development and Foreign Languages, Mátrai út 36, 3200 Gyöngyös, Hungary, e-mail:

davidlo@karolyrobert.hu

****Szent István University, Faculty of Economics and Social Sciences, Institute of Regional Economics and Rural Development, Páter Károly út 1, 2100 Gödöllö, Hungary, e-mail: vasa.laszlo@gtk.szie.hu

The aim of our research was to develop a dairy farm technology planning system which models the material flow and value chain of a sample dairy farm. By this model, widespread sensitivity analyses can be made to promote an economically and professionally more sound decision-making by modifying the main parameters that has an effect on the system. Risk analysis might also be made if stochastic simulation is used and some parameters of the technology planning system are managed as probability variables. The most important risk factors' effect were analyzed on the result and costs. The elaborated technology planning system has new elements compared to other decisionsupport systems on the market, which is suitable for soundly preparing and supporting decisions and analyzing the risk of dairy farms. The system can be used in an efficient way to model dairy farms with herd from 100 to $1500 \mathrm{cows}$, to determine risk factors and to even provide controlling tasks.

Keywords: dairy enterprise; decision support system; risk; simulation 


\section{Introduction}

Material flow processes of animal husbandry constitute a compound system which involves the procurement, stocking and marketing tasks as well. Material flow processes are closely linked with resource management, operation and demand management. The optimal production and logistics strategy can only be determined in the light of these circumstances. These processes are much more complex in the animal husbandry than in a conventional enterprise, since biological laws must also be considered at the timing of processes.

Dairy sector is in a long-term crisis in Hungary, as well as in other countries of the world; its profitability has been declining in past years. Farms must try to make their farming as efficient as possible with every available tool so to avoid the dispose of herd and the closure. The system approach application of logistics can be such an instrument in the processes of animal husbandry.

The latest definitions and interpretations for logistics manage the whole inventory of a company (material, financial-accounting, human resource, etc.) in a standard way. An objective of the integrated corporate system is also this, which means the system approach analysis of the processes at an animal farm. Animal husbandry and the dairy sector are in a long term crisis, so to improve efficiency the optimization of both external and internal processes is needed. Thus, we set out as a general objective of our research to give efficient tools for decision-makers that consider the characteristics of animal husbandry to establish a profitable dairy farming by applying the present methods of mathematics and operations research. In our research a dairy farm technology planning system was developed that models the material flow and value chain of a sample dairy farm. By this model widespread sensitivity analyses can be made to promote an economically and professionally more sound decision-making by modifying the main parameters that has an effect on the system. Stochastic elements of technology and economic environment can significantly influence the future effect of the decisions. This technology planning system for dairy farms makes possible to analyze risk by stochastic simulation if some elements are treated as probability variables. We analyzed the most important risk factors' effect on the results and costs as well.

\section{Literature Review}

Several researchers dealt with dairy farm decision support systems. However, most frequently these systems are used to optimize just an enterprise or a small part of a complex process and not a whole farm. For instance, feeding decision support systems were elaborated to a very wide extent. 
By CAMDAIRY [12] we can investigate how much milk can be produced by lactating heifers from the available feed. The inputs are: the breed of heifer, weight and the amounts of feeds (on-farm and bought-in). As the output of the tool we get information about whether the target milk production will be achieved or not.

CAMBEEF [13] is a tactical DS tool for investigating scenarios dealing with feeding management of grazing beef cattle. CAMBEEF and CAMDIARY also calculate the amount of metabolisable energy (ME), crude protein (CP) and other indices required to achieve the targets. These tools can give the scenario of leastcost ration.

GRAZFEED [10] is part of the GRAZPLAN decision support project [7]. It assesses the nutritive value of a pasture grazed by specified animals and shows the extent to which the targeted live weight gain can be achieved through supplementation.

RUMNUT [3] is designed to calculate the nutritional requirements of the cattle.

HIGRO [6] is developed for the feeding and management of dairy replacement heifers, but it also allows the user to address decisions that are long-term compared to other DS tools.

DAIRYPRO [15] is a combination decision support and expert system consisting of two modules. The one can be used for short-term decisions and the other for long-term, strategic decisions. It is designed to help dairy farmers in Australia to make strategic decisions about their farm. It uses real farm survey data and opinions from experts.

Main task of mathematical modeling is to set up the most precise models as possible about the processes of a given system and to evaluate the results of the model. However, when creating the model some type and extent of uncertainty must be also considered. Biological processes contain several stochastic factors which use in the model requires great care. For programming the stochastic variables there are some methods, but the most frequently used is Monte-Carlo simulation. Monte-Carlo method was elaborated by John Neumann in 1945. Monte-Carlo methods are numerical techniques that use random quantities for solving the mathematical models and evaluate their parameters in a static way. The main point of the method is that the values of probability variables are chosen randomly by the probability distribution assigned to some uncertain runs which are used in one test of the simulation [22;19]. In the model to be analyzed we set the influencing factors and their potential intervals, their probability distributions and the relations among the variables. The intervals and the distribution values of the variables are created by random number generator. The computerized models must be run several times (usually 1000-10000 times) and in the end an expected value and a confidence interval of standard deviation at a given significance level will be got for the result variable to be determined [18]. Usually, some income 
category is given as a result variable and the probability of reaching a lower or higher value is analyzed as risk [19]. By increasing the number of runs, the distribution of result variables can be given at an optional accuracy [9]:

$\psi=E_{\pi}\{U(X)\}=\int U(x) \pi(x) d x$

where $X=\{\theta, \phi\}$ is a vector consisting of decision parameters $(\theta)$ and state variables $(\phi), \pi(x)$ is a distribution function of $x . U(x)$ is a utility function, $E_{\pi}()$ function gives the expected utility at a given distribution. The advantage of this method is that the model may be run separately by decision variants, so the risks of different variants are comparable. The above-described integral can be determined numerically as [14]:

$\psi=\frac{1}{k}\left\{U\left(x^{(1)}\right)+\ldots+U\left(x^{(k)}\right)\right\}$

where $k$ means the number of tests (runs or experiments).

This method was used in several research fields: [5] used it for modeling the air pollution, this simulation method was applied by [11] for modeling drought, by [14] for the spread of pig farms' diseases and by [2] for managing the risk of bioethanol production. [4] elaborated a simulation model to optimize dairy herd size according to Dutch dairy farms' data. [8] investigated by a simulation model the effects of management, market and biological factors on costs if the herd is fed with on-farm feeds. [21] analyzed the costs of milk transport and the carbondioxide emission of transportation under various seasonal conditions with simulation model in Ireland. [1] studied the influencing factors of productivity in pig enterprise with simulation methods in the Northern Great Plain Region in Hungary. [17] measured the technological risks in dairy, pig and poultry sectors.

For setting up and running these simulations, several softwares have been developed: the Excel-based Crystal Ball (Decisioneering, Inc.) and @Risk (Palisade Corporation) softwares are easy to use and excellent for making such analyses.

\section{Materials and Methods}

\subsection{Description of the Technology Planning System}

The examinations started with detailed exploration of material and value flow processes on dairy farms, which was needed for setting up a sample farm technology planning model which is suitable for analyzing the effects of varying some factors on the result of farming. 
The material flow and value chain of dairy farms for the technology planning system are summarized in Figure 1. Input and output prices are shown on the top of the chart and in the middle of the picture material flow processes are presented. If the prices are assigned to the natural parameters of material flow, cost and income may be calculated and also the profitability and other efficiency factors may be determined. In the technology planning system the physical and value flow processes are presented in a connected way. Any physical flow process can be evaluated in the value chain and the modification of the value chain's input data immediately appears in the cost and revenue calculations and through this in the profitability indices. Profitability indices may be chosen optionally.

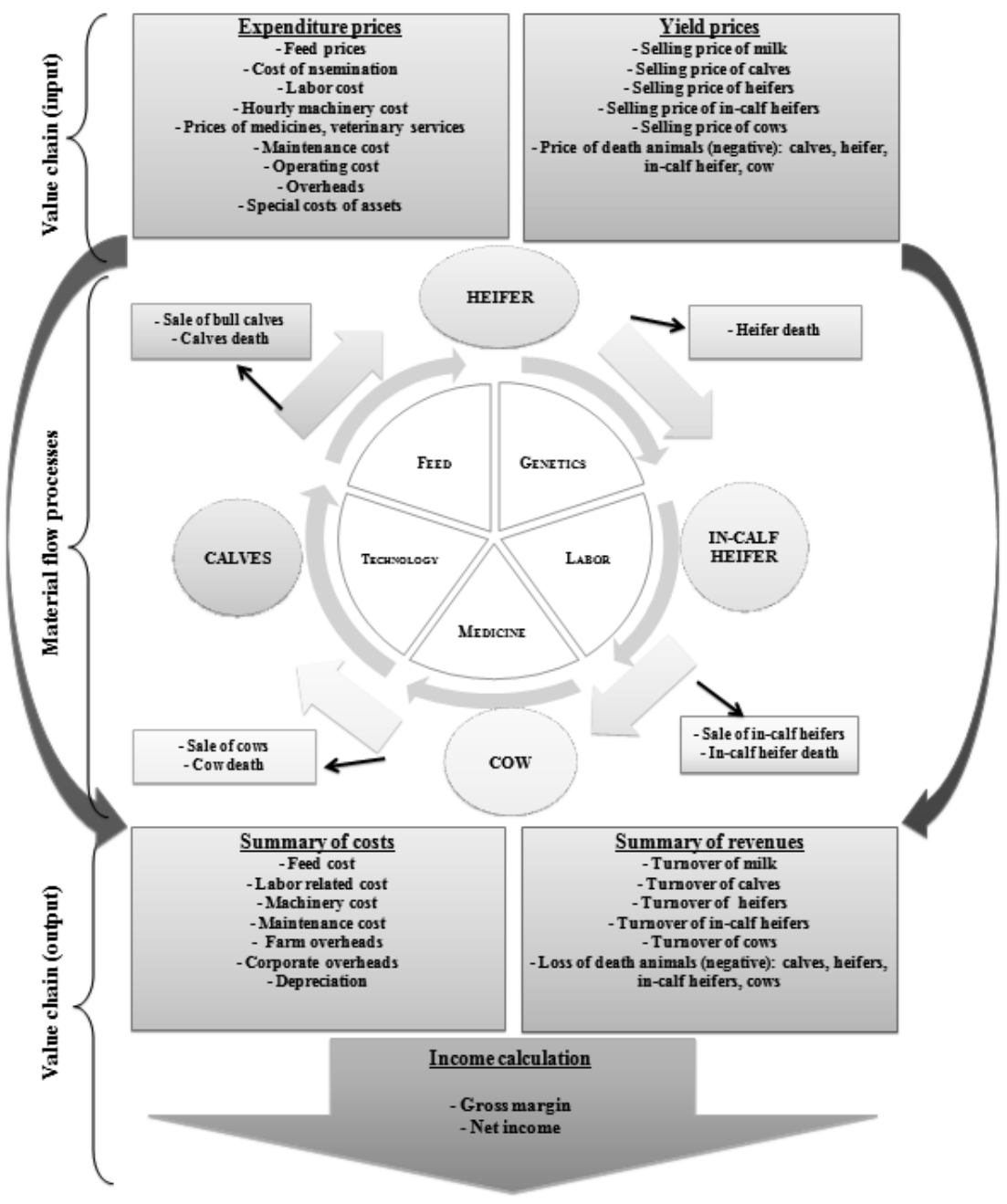

Figure 1

Material flow processes and value chain of dairy farms 
The technology planning system consists of five basic modules. Figure 2 shows the schema of the model where the basic models are on the top of the chart. In the first module there are basic parameters that are needed for the herd size calculations. By age groups we can set the age and weight of getting into and out from a group, weight gain, animal yield and the rate of mortality as well.

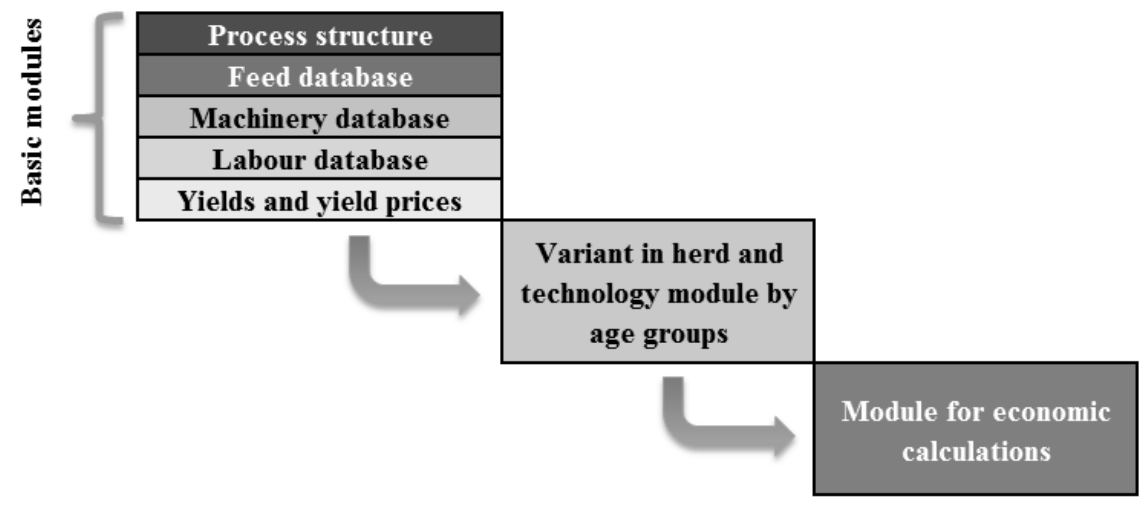

Figure 2

Schema of the technology planning system

In the database of feeding the type and price of feeds, concentrates can be set and we can also choose whether the feed is on-farm or bought-in. In the model there is a basic list, but it can be enlarged or narrowed.

In the database of machinery there are machines available and the cost of working for one hour. The list, number and costs of machines might be set optionally.

In the database for labor the number of workers, the scope of activities, workplaces and hourly wages are listed.

In the module of yields milking groups and the specific milk quantity by milking groups might be adjusted. Furthermore, the prices of marketed products (milk, livestock, etc.) and the specific losses from dead-on-farm animals are listed here.

If raw data are set, the program automatically and simultaneously calculates the effect of changes on the operation of the sample farm. Based on the raw data, the program calculates first the variant in herd by age groups in the module of herd variant and technology. In the first model variant we set 5 age groups (calf I, calf II, heifer, in-calf heifer, cow), however, under other circumstances these groups might be enlarged or narrowed. In the variant in herd the program counts the feeding days by age groups as well. Based on this, feed cost will be got if the specific feed ration is multiplied with the unit feed cost and the number of feeding days. Feed rations were determined by feed recipes of Hungarian dairy farms. According to the cows' production, 6 feeding groups were formed (dry cows, preparatory group, heavy milker I, heavy milker II, medium and low milker groups). Obviously, these groups might be varied as well. 
For the calculations of labor and machinery the data (number of workers, number of machines, number of working hours, hourly wages and costs) were set by farm practice in Hungary. By the total number of working hours and wages or costs the program calculates the labor and machinery costs by months and at an annual level as well.

At the calculation of yields the system accounts the dead animals (with negative sign) and the marketed products (livestock, milk) in natural measurement unit (kg, liter). The quantities calculated in natural measurement unit are multiplied with yield prices and we will get the turnover from selling goods for each age group, which is the difference of losses and the turnover from sales.

The monthly and annually calculated costs and turnover are summarized in the socalled economic calculations module. From the difference of turnover and costs the profitability of the sample farm will be immediately seen by the various profitability indices.

By giving the basic parameters, a model shall be got where by changing some parameters, the effect of our decisions on the results shall be immediately seen. The results might be compared with the average values of a country or region to check the correctness of the calculations. However, this model is not suitable for quantifying risks. Therefore, simulation methods were needed to be applied to measure the error. By these methods the likelihood can be determined that the dairy farm shall operate in economic sense. Information is received about risk factors which are really significant for the economics indices.

Probit analysis, counting with the probability distribution of risk factors' occurring, takes notice of the risk factors' joint effect on the dependent variable; furthermore, if there is correlation between the risk factors, it also records its strength and direction.

By the results of the simulation runs the probability of having advantageous cases (e.g. the probability of having a farm at breakeven point) might be determined by density functions. These analyses may be executed for some turnover, cost or income categories as well.

\section{Results and Discussion}

\subsection{Case Study}

For the elaboration of the technological planning system in this case study we used the technology of a dairy farm in Hungary. The average herd size is 1,050 cows, which represents the large-sized dairy farms in Hungary. Milking cows are kept in two stalls with resting pens; their capacity is 528 cows each. Cows in the 
calving and hospital barns are reared in groups, calves are kept in cages and in small groups. Heifers and in-calf heifers are also reared in small groups. The farm has a carousel milking parlor with 80 milking stalls. Milking is done three times a day with FULLWOOD milking plant. The farm has automatic funnel remover, cooling system and automatic washer system. Feed distribution is performed by PEECON piston feed wagons. Drinkers are automatic and heated. There is a slurry system on the farm.

The basic production and technological data were given by this farm's database of 2010 and the missing and incorrect data were collected from literature or generated by the parameters of other 16 examined dairy farms in Hungary. For the risk analysis of the technology planning system Crystal Ball program package was used.

To verify the model, the results were compared with the database of Research Institute of Agricultural Economics (Hungarian abbreviation: AKI). The Farm Accountancy Data Network (FADN) is the representative information system of the European Union that evaluates the assets and liabilities, financial position of farms.

In the FADN there are 32 sample farms in the Northern Great Plain Region of Hungary. Among the farms there are 22 individual and 10 corporate farms. Dairy herd of the individuals is 1187 cows; the average farm size is 12 cows. The corporate farms' total herd is 3716 heads; the average for one farm is 371 dairy cattle. The total herd of the examined 32 farms is 4903 cows which is $6.22 \%$ of the population in the Northern Great Plain Region. The produced milk yield was more than 35.5 thousand tons in 2010.

Specific turnover on 2010 prices was 4,223 \$/cow. The Hungarian average turnover on corporate farms was 3,391\$/cow. However, the specific values fluctuated between 2,633 and 4,319 $\$$ in 2010 , so it can be stated that our calculation results reflect real results, since the value is within the given interval. National data of FADN shows that farms keeping more than 150 cows realized $2,820 \$$ turnover in 2010 [16], thus the sample farm reached this turnover above average.

The costs and cost structure of the sample farm and FADN average are shown in Table 1. Feed costs were almost the same on the sample farm and on the corporate farms $(1,910 \$ / \mathrm{cow})$, however, the rate of feeding cost was higher on the sample farms $(75,88 \%)$ than on FADN farms $(60 \%)$. Specific labor cost was much higher on the test farms (788 \$/cow), but the sample farm's value is also in the determined interval of FADN database (96-1,100 \$/cow). In the case of machinery cost a higher value was measured (168-178 \$/cow) than on the test farms. Depreciation is almost in the same level in both cases (168-178 \$/cow). Considering the direct cost, the sample farm operated with a lower cost level $(2,517 \$ / \mathrm{cow})$ than the national average $(3,128$ \$/cow). The interval of FADN database fluctuated between 2,335 and 4,449 \$/cow in 2010 . 
Table 1

Direct cost and cost structure of the sample farm and the corporate test farms (FADN)

\begin{tabular}{|l|c|c|c|c|}
\hline \multirow{2}{*}{ Cost } & \multicolumn{2}{|c|}{ Sample farm (1050 cows) } & \multicolumn{2}{c|}{$\begin{array}{c}\text { Hungarian average of corporate } \\
\text { farms (FADN) }\end{array}$} \\
\cline { 2 - 5 } & US \$/cow & cost rate & US \$/cow & cost rate \\
\hline Feed cost & 1,910 & $75,88 \%$ & 1,878 & $60,04 \%$ \\
\hline Labor cost & 272 & $10,81 \%$ & 788 & $25,19 \%$ \\
\hline Machinery cost & 157 & $6,24 \%$ & 293 & $9,37 \%$ \\
\hline Depreciation & 178 & $7,07 \%$ & 169 & $5,40 \%$ \\
\hline Direct cost & $\mathbf{2 , 5 1 7}$ & $\mathbf{1 0 0 \%}$ & $\mathbf{3 , 1 2 8}$ & $\mathbf{1 0 0 \%}$ \\
\hline
\end{tabular}

Gross profit of the sample farm was 1,706 \$/cow on 2010 prices (Figure 3). The average value of corporate test farms was $263 \$ / \mathrm{cow}$, but there was a high dispersion in 2010, because the values moved between -1,417 and 1,753 \$/cow.

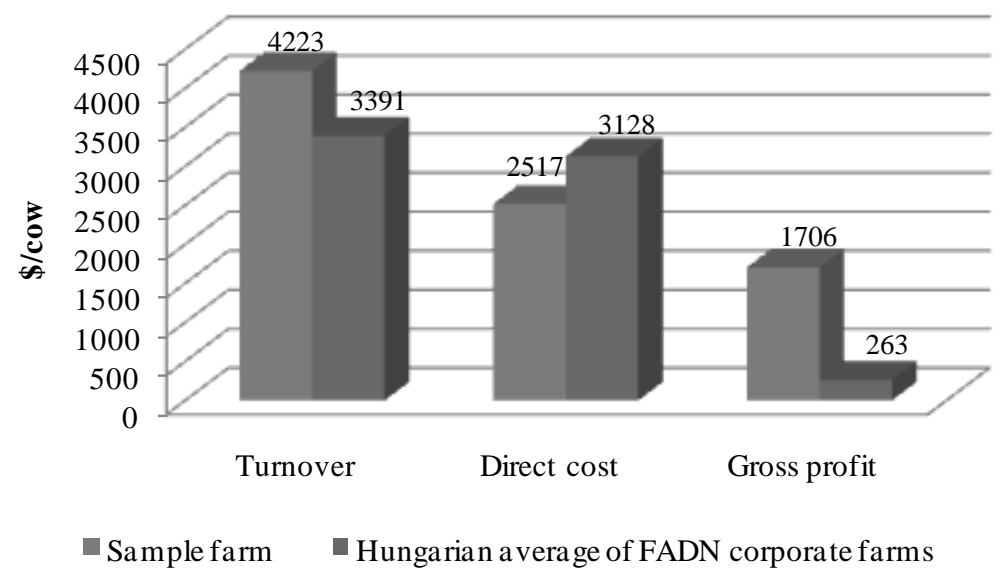

Figure 3

Turnover, direct cost and gross profit of the sample farm and FADN corporate farms

After this, risk was validated according to inputs, outputs and technological factors as well. The number of simulation was 10.000 and according to this the average income was 101.4 US \$/cow, which is almost the same with median (100.8 US \$/cow), so in 50 percent of the cases we can reach higher income than 100.8 US \$/cow. The probability of reaching zero profit is almost $70 \%$. Considering the total cost, the mean and the median coincides again $(4,131 \mathrm{US}$ $\$ /$ cow), the range of distribution is very wide, it fluctuates between 3,689 and 4,597 US \$/cow. The fluctuation is higher in case of the turnover $(3,497-5,054$ US $\$ /$ cow), the mean is 4,228 US $\$ /$ cow. 
After elaborating the model, the factors were determined that was managed as probability variable in the stochastic model, these are: culling rate of milking cows $(\%)$, mortality rates for each age group (\%), calf yield rate $(\%)$, service period (days), feed prices $(\$ / \mathrm{kg})$, specific machinery costs (\$/working hour), yield prices $(\$ / 1, \$ / \mathrm{kg})$ and average daily milk production (1/day).

In the simulation the basic technological parameters were set with normal distribution, such as the culling rate of milking cows (\%), mortality rates for each age group (\%),calf yield rate (\%) and the yields (average daily milk production (l/day)) and the yield prices. Feed prices were with beta-distribution and machinery costs were built in with triangle distribution.

The influencing factors and the influential rate of net income, turnover and production cost might be well presented on Tornado-charts (Figures 4-6). On the charts the percentages show that at what extent the given factor's distribution/uncertainty contributes to the variance of the dependent variable (net income, turnover, production cost). In a more simple way in the literature it is said that it shows the effect of random variables on the forecasted value.

Examining the influencing factors of the result variables, it can be stated that the net income is affected by the yields of the diary farm, after that the feed cost (the highest is the grain feed, lucerne senage and the cost of milking concentrate) (Figure 4). Among the biological factors, calf yield is the most important.

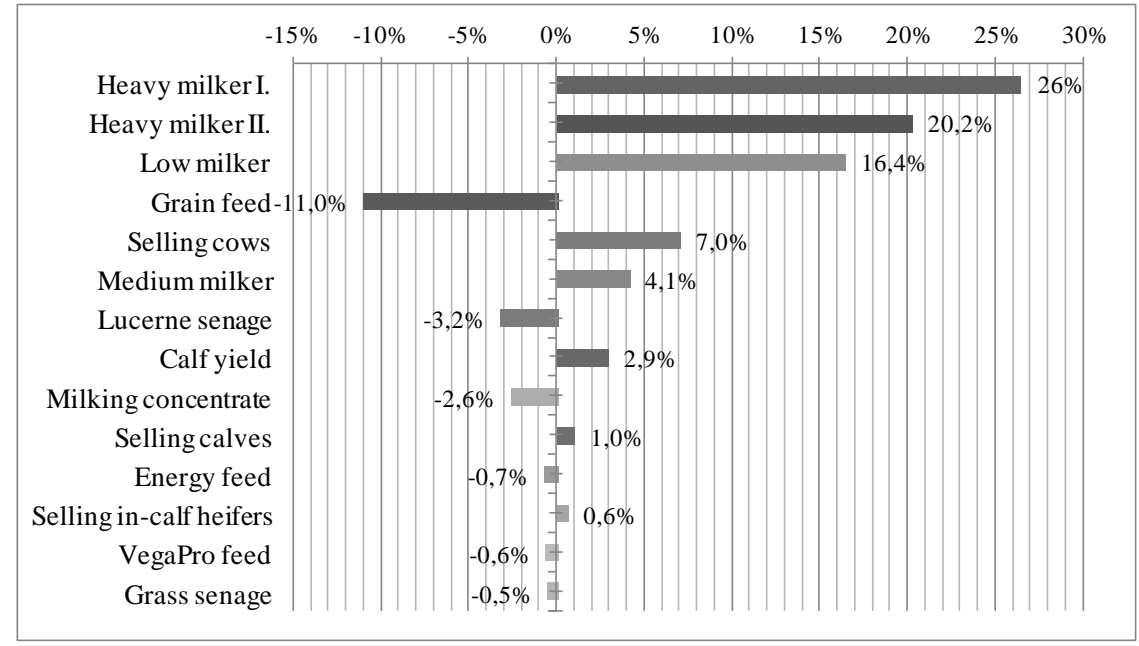

Figure 4

Influencing factors of net income

Basic grain feed, lucerne senage and the cost of milk feed among feeds and calf yield and service period among biological factors have the highest influence on direct cost (Figure 5). 
Among the yields, the milk production's effect on turnover is of great significance (Figure 6). Among biological factors, calf yield is the most important, but the service period, calves and cow death are also significant.

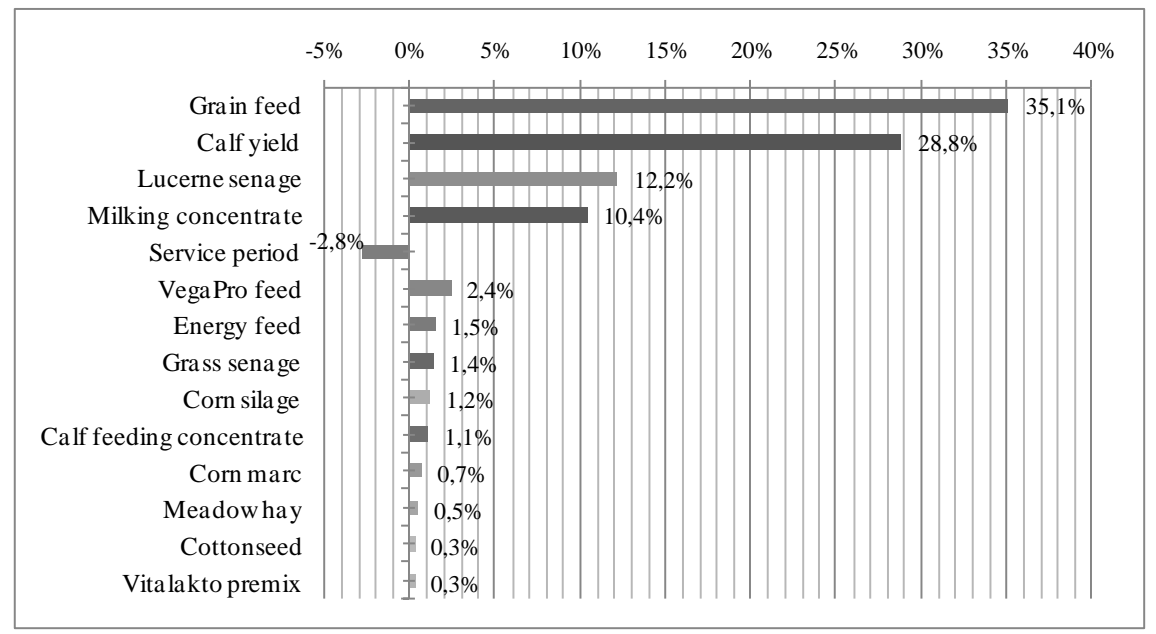

Figure 5

Influencing factors of production cost

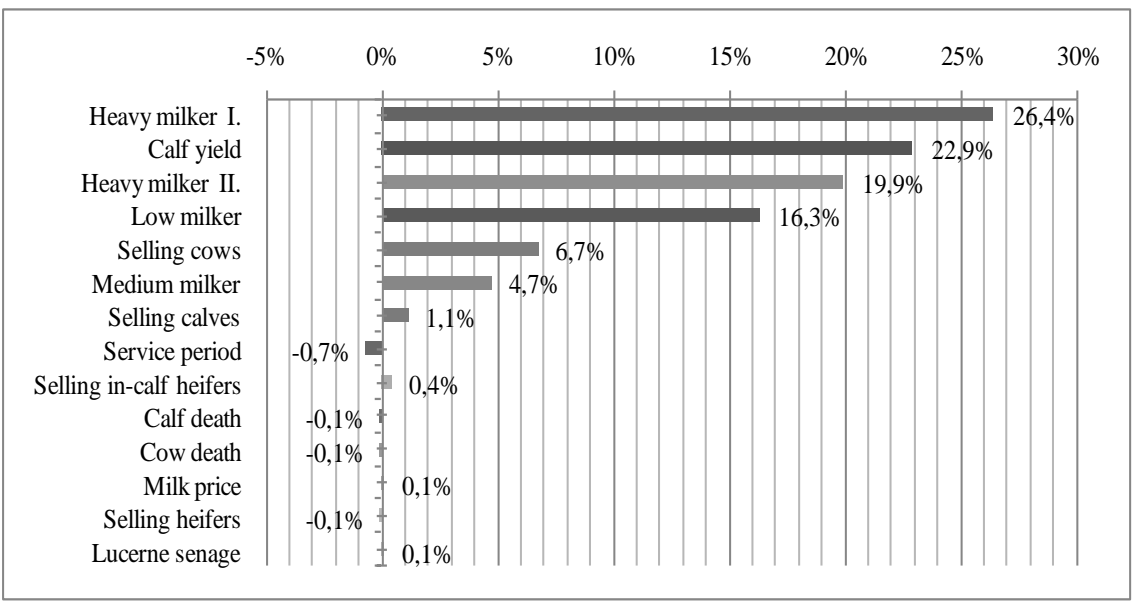

Figure 6

Influencing factors of turnover

\section{Conclusions}

Within animal husbandry cattle farming is of great significance. Past years the profitability and competitiveness of the Hungarian bovine sector has been declining, so it is of high priority to ensure tools for decision-makers that makes 
farming more efficient. The objective of our research work was to explore the supply and value chain of dairy farms, to present the significance and cost of logistics processes and to elaborate a decision-support system. The elaborated technology planning system has novel elements compared to other decisionsupport systems on the market, which is suitable for soundly preparing and supporting decisions and analyzing the risk of dairy farms. The system can be used in an efficient way to model dairy farms with herd from 100 to 1500 cows, to determine risk factors and to even provide controlling tasks. In our research we elaborated a decision-support technology-planning system for dairy farms that follows the whole material flow and value chain, in which the physical and value flow processes appear in a related way. Any physical flow process can be evaluated in the value chain and the modification of the value chain's input data immediately appears in the cost and revenue calculations and through this in the profitability indices.

We complemented the technology planning system with a stochastic module which is suitable for measuring risk. Examining the influencing factors of the result variables in the modeled sample farm, I stated that the net income is affected by the yields of the diary farm, after that the feed cost (the highest is the basic grain feed, lucerne senage and the cost of milk feed). Among the biological factors, generation of calves is the most important. I found that basic grain feed, lucerne senage and the cost of milk feed among feeds and generation of calves and service period among biological factors have the highest influence on the total cost.

\section{Acknowledgement}

This publication is supported by the TÁMOP-4.2.2/B-10/1-2010-0024 project. The project is co-financed by the European Union and the European Social Fund.

\section{References}

[1] Balogh P: Nagyüzemi sertéstartás eredményességét meghatározó tényezők gazdasági elemzése az Észak-alföldi Régió néhány gazdaságában, Ph.D. dissertation, Debreceni Egyetem, Debrecen, 2004

[2] Bamikole A, Petrie D, Görgens J.: Economic Risk Assessment of Advanced Process Technologies for Bioethanol Production in South Africa: Monte Carlo analysis, 2011, Renewable Energy 36, pp. 3178-3186

[3] Chamberlain AT: RumNut v3.3 Users Manual, 1996

[4] Demeter RM, Kristensen AR, Dijkstra J, Lansink AGJMO, Meuwissen MPM, Van Arendonk JAM: Multi-Level Hierarchic Markov Process with Bayesian Updating for Herd Optimization and Simulation in Dairy Cattle, Journal of Dairy Science, 2011, Vol. 94, Issue 12, pp. 5938-5962 
[5] Dimov I, Georgieva R, Ostromsky T.: Monte Carlo Sensitivity Analysis of an Eulerian Large-Scale Air Pollution Model, Reliability Engineering and System Safety, 2011, doi:10.1016/j.ress.2011.06.007

[6] Dobos R, McPhee M, Ashwood A, Alford A: A Decision Support Tool for the Feeding and Management of Dairy Replacement Heifers, Environmental Modelling \& Software 16, 2001, pp. 331-338

[7] Donnelly JR, Moore AD, Freer M: GRAZPLAN: Decision Support Systems for Australian Grazing Enterprises I. Overview of the GRAZPLAN Project, and a Description of the Met Access and LambAlive DSS, Agricultural Systems 54, 1997, pp. 57-76

[8] Finneran E, Crosson P, O'kiely P, Hallo L, Forristal D, Wallace M: Stochastic Simulation of the Cost of Home-produced Feeds for Ruminant Livestock Systems, The Journal of Agricultural Science, Vol. 150, 2012, pp. 123-139

[9] Fishmann GS: Monte Carlo. Concepts, Algorithms and Applications, Springer, New York, 1996

[10] Freer M, Moore AD, Donnelly JR, 1997. GRAZPLAN: Decision Support Systems for Australian Grazing Enterprises II. The Animal Biology Model for Feed Intake, Production and Reproduction and the GrazFeed DSS. Agricultural Systems 54, 77-126

[11] Gil M, Garrido A, Gómez-Ramos A: Economic Analysis of Drought Risk: An Application for Irrigated Agriculture in Spain, Agricultural Water Management 98, 2011, pp. 823-833

[12] Hulme DJ, Kellaway RC, Booth PJ, Bennett L: The CAMDIARY Model for Formulating and Analysing Dairy Cow Rations, Agricultural Systems 22, 1986, pp. 81-108

[13] Irwin C, Kellaway RC: CamBeef: Ration Formulation for Feedlots and Grazing Supplementation - User Manual, University of Sydney, 1993

[14] Jorgensen E: Calibration of a Monte Carlo Simulation Model of Disease Spread in Slaughter Pig Units, Computers and Electronics in Agriculture 25, 2000, pp. 245-259

[15] Kerr DV, Cowan RT, Chaseling J: DAIRYPRO- a Knowledge-based Decision Support System for Strategic Planning on Sub-Tropical Dairy Farms, I. System Description, Agricultural Systems 59, 1999, pp. 245-255

[16] Keszthelyi Sz, Pesti Cs: A tesztüzemi információs rendszer eredményei, Budapest, Agrárgazdasági Kutató Intézet, 2012

[17] Kovács S: A technológiai kockázat elemzésének módszerei az állattenyésztésben, Ph.D. dissertation, Debreceni Egyetem, Debrecen, 2009 
[18] Kovács S, Ertsey I, Balogh P: Bayesi statisztikán alapuló Monte Carlo szimuláció alkalmazása a tojótyúk nevelés technológiai kockázatának vizsgálata során, Agrárgazdaság, Vidékfejlesztés, Agrárinformatika AVA3 nemzetközi konferencia CD-kiadvány, Debrecen, 2007

[19] Nagy L: A kockázatelemzés néhány lehetősége a növénytermesztés döntéstámogatásában, Ph.D. dissertation, Debreceni Egyetem, Debrecen, 2009

[20] Pokorádi L, Molnár B: Monte-Carlo szimulációs valószínűségi bizonytalanságelemzés szemléltetése, Repüléstudományi Közlemények különszám, 2010. április 16.

[21] Quinlan C, Keane M, Connor D, Shalloo L: Milk Transport Costs Inder Deffering Seasonality Assumptions for the Irish Dairy Industry, International Journal of Dairy Technology, Vol. 65, Issue 1, 2012, pp. 2231

[22] Russell RS, Taylor BW: Operations Management, Focusing on Quality and Competitiveness, New Jersey, 1998, Prentice Hall, pp. 610-613 